
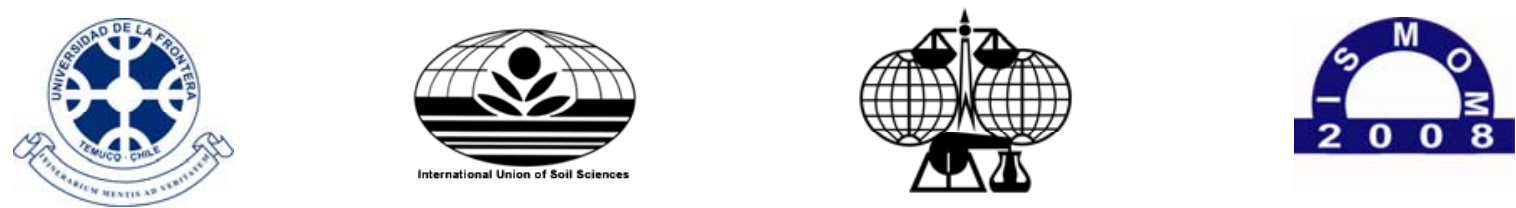

$5^{\text {th }}$ International Symposium ISMOM 2008 - November $24^{\text {th }}-28^{\text {th }}, 2008$ - Pucón, Chile

Keynote papers

\title{
K-8
}

\section{Bioavailability of Phosphorus and Micronutrients in the Soil-Plant-Microbe Continuum}

\section{Z. Rengel*}

Soil Science and Plant Nutrition, School of Earth and Geographical Sciences, University of Western Australia, M087, Crawley WA 6009, Australia.*E-mail: Zed.Rengel@uwa.edu.au

\section{Introduction}

An increasing need to produce food for the expanding world population creates significant pressure on suitable land already in production and requires continuous expansion of foodproducing ecosystems into less fertile areas. In every such food-producing system, crops and pastures must be provided with sufficient nutrients for vigorous growth and high outputs, putting an emphasis on understanding soil-plant microbe interactions governing nutrient acquisition by plants. This review will summarise the available knowledge on relevant interactions underlying plant acquisition of $\mathrm{P}$ and micronutrients (with an emphasis on $\mathrm{Mn}$ ).

Soils resulting in $\mathrm{P}$ and micronutrient deficiency in crops and pastures are abundant in the world, but such nutrient deficiency arises from poor $\mathrm{P}$ and micronutrient mobility rather than low total amounts present in soil (Rengel, 2001). Hence, the plant-available nutrient fraction and the concentration in the soil solution may be insufficient to satisfy plant requirements (Jorquera et al., 2008; Rengel and Marschner, 2005).

Around $90 \%$ of the total P use in the world today is for food production (Jasinski, 2006). Hence, modern agricultural systems are dependent on continual inputs of $\mathrm{P}$ fertilizers processed from phosphate rock. Yet, the world reserves of phosphate rock are becoming increasingly scarce, and estimates are they will be depleted within 50-100 years, with a global peak in usage of P reserves occurring by 2040 (Jasinski, 2006). While the exact timing might be disputed, it is widely accepted that the quality of $\mathrm{P}$ rock is decreasing and cost increasing (indeed, the price of phosphate rock has risen 7-fold in the 14 months since Feb 2007) (Cordell, 2008).

\section{The rhizosphere}

The rhizosphere (a layer of soil around the root that is influenced by the root) extends up to a few millimetres from the root surface into the surrounding soil. Bioavailability of $\mathrm{P}$ and micronutrients in the rhizosphere is controlled by soil properties, plant characteristics, and the interactions of plant roots with microorganisms (Rengel and Marschner, 2005).

The fluxes of organic anions exuded into the rhizosphere by roots were rather small in comparison with the flux of $\mathrm{H}^{+}$or $\mathrm{OH}^{-} / \mathrm{HCO}_{3}{ }^{-}$(Hinsinger, 2001). The balance between excretion of $\mathrm{H}^{+}$and $\mathrm{OH}^{-} / \mathrm{HCO}_{3}{ }^{-}$depends on the cation/anion uptake ratio. Greater excretion of $\mathrm{H}^{+}$ (accompanying greater absorption of cations than anions) results in rhizosphere acidification; the reverse occurs when uptake of anions exceeds that of cations, with excretion of $\mathrm{OH}^{-} / \mathrm{HCO}_{3}{ }^{-}$ 

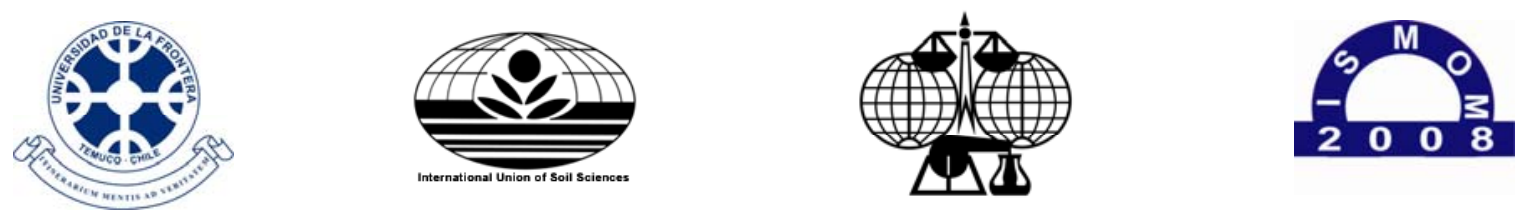

$5^{\text {th }}$ International Symposium ISMOM 2008 - November $24^{\text {th }}-28^{\text {th }}, 2008$ - Pucón, Chile

Keynote papers

exceeding that of $\mathrm{H}^{+}$(Tang and Rengel, 2003). Solubility of micronutrient-containing and Ca-P complexes increases with increasing soil acidity. Solubility of $\mathrm{Zn}$ increases 100-fold with each unit decrease in pH (Rengel, 2001).

For diffusion-supplied micronutrients, larger amounts are transported toward roots if a large concentration gradient between the root surface and the bulk soil can be maintained by vigorous nutrient uptake at the root surface. However, when a capacity of root cells to take up nutrients exceeds the rate of nutrient replenishment at the root surface, the uptake rate is governed by the nutrient supply rather than by the capacity of plants to take up nutrients (Rengel, 1993). Therefore, an increased capacity of root cells to take up nutrients is expected to be of secondary importance as an efficiency mechanism for diffusion-supplied micronutrients, with a greater effect achieved by increasing the plant capacity to exude chelating and other agents into the rhizosphere, resulting in increased solubilisation and conversion of nutrients into plant-available forms.

Plants exude a variety of organic compounds (carboxylate anions, phenolics, carbohydrates, amino acids, enzymes, other proteins, etc.) and inorganic ions (protons, phosphate and other nutrients, etc.) into the rhizosphere to change chemistry and biology of rhizosphere and enhance adaptation to a particular environment (Crowley and Rengel, 1999). Complete understanding of complex interactions governing the relationship of quantity and differential composition of root exudates with soil properties as well as plant genotype and phenotype is still far away. One of the reasons for such a statement stems from inadequate experimental methods to assess spatial and temporal variability in root exudation as well as to follow the fate of various organic and inorganic compounds exuded from roots in soil (cf. Shen et al., 2003) and their differential effectiveness in increasing availability of soil $\mathrm{P}$ and micronutrients (Rengel, 2002). The interactions between microorganisms and plants at the soil-root interface add additional layers of complexity.

\section{Physiological traits important in P-use efficiency}

In acidic soils, $\mathrm{P}$ is fixed in either $\mathrm{Al}$ or Fe complexes, whereas in calcareous soils of higher $\mathrm{pH}$ it is Ca phosphate complexes. In addition, there is a large pool of organic P in most soils (can be as high as $80 \%$ of the total P) (Hinsinger, 2001). Enhanced acquisition of $\mathrm{P}$ from soils relies on morphological, physiological, biochemical and molecular adaptations (eg. Lambers et al., 2006; eg. Liu et al., 2005; Marschner et al., 2006; 2007; Nuruzzaman et al., 2006; Shu et al., 2007b; Wang et al., 2007b). P-use efficiency may be underpinned by increased capacity to 1) transform nonavailable P forms into plant-available ones, 2) explore a larger soil volume more thoroughly, and/or 3) transport P into the root cells.

Given differences in P fractions in acid vs neutral and alkaline soils, mechanisms allowing plants to access sufficient $\mathrm{P}$ for growth might differ among soils. However, for wheat grown in either neutral or acidic soils, $\mathrm{P}$ acquisition was dependent on extensive root exploitation and high phosphatase activity in the rhizosphere (especially alkaline phosphatase and diesterase, indicating microbial facilitation of organic P mineralisation) (Marschner et al., 2005b). 

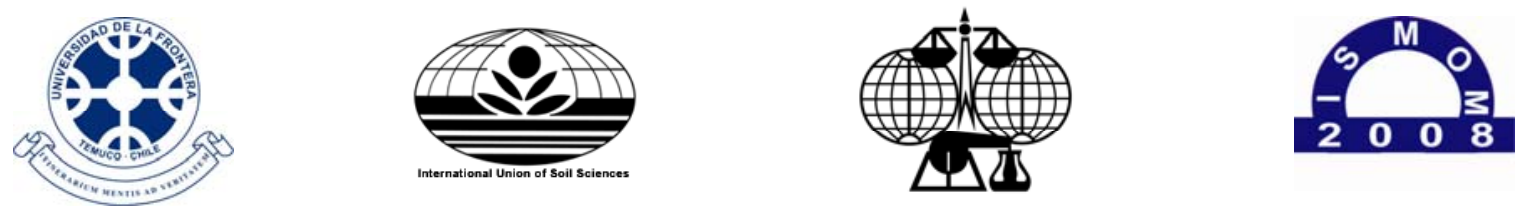

$5^{\text {th }}$ International Symposium ISMOM 2008 - November $24^{\text {th }}-28^{\text {th }}, 2008$ - Pucón, Chile

Keynote papers

\section{Root morphology}

Plants growing in P-deficient soil allocate a greater proportion of assimilates to root growth and tend to have fine roots of a small diameter and therefore a large surface area. P-efficient barley (Gahoonia et al., 2001) and cowpea cultivars (Krasilnikoff et al., 2003) have longer root hairs allowing them to take up more $\mathrm{P}$ in comparison with P-inefficient genotypes. P-deficient Lupinus angustifolius increased the primary root elongation and developed a large number of the cluster-like first-order lateral roots with dense root hairs, thus allowing efficient $\mathrm{P}$ acquisition under low $\mathrm{P}$ supply (Wang et al., 2008). Fine roots and especially root hairs effectively scavenge $P$ from soils because of a large surface area of contact with the soil.

The shoot $\mathrm{P}$ status may regulate the formation of cluster roots, as specialised structures of selected plant species for thorough exploration of the soil volume (Lambers et al., 2006; Shu et al., 2007b). However, the form of $P$ in soils may also regulate cluster root formation (Shu et al., 2007a; Shu et al., 2007b). In addition, the development of cluster roots can respond to a presence of organic matter adjacent to the root (Adams and Pate 1992).

\section{Exudation of organic compounds}

Under P deficiency, plants exude a wide range of organic compounds (carboxylates, enzymes, phenolics, etc.) to increase mobilisation of $\mathrm{P}$ from sparingly soluble sources (eg. Neumann and Römheld, 1999). Typical carboxylates (organic acid anions) found in root exudates of P-deficient plants include citrate, malate, malonate, acetate, fumarate, succinate, lactate and oxalate (see Rengel, 2002). In barley, P-use efficiency may be linked to the capacity of genotypes to increase exudation of citrate as an organic acid anion with a strong capacity to mobilise P (Gahoonia et al., 2000). Interestingly, citrate exudation by Lupinus albus roots increased only due to localized Fe-P application, but not when other P sources were applied (Shu et al., 2007a; Shu et al., 2007b).

Carboxylates may be exuded by P-deficient roots at appreciable rates [an average rate of 0.57 $\mathrm{nmol}$ citrate $\mathrm{cm}^{-1}$ root $\mathrm{h}^{-1}$ for Brassica napus (Hoffland et al., 1989) or 200-400 nmol oxalate $\mathrm{g}^{-1}$ soil $\mathrm{h}^{-1}$ by Cassia spectabilis, with rhizosphere soil containing at least $29 \mu \mathrm{mol}$ oxalate $\mathrm{g}^{-1}$ soil (Radersma and Grierson, 2004)]. Exuded carboxylate anions may have a role in solubilisation of mineral nutrients and as growth substrates for microorganisms. Because carboxylates are excellent substrates for microbial growth, high concentrations of carboxylates may occur only temporarily and only at rapidly growing root apices not yet densely colonised by microorganisms.

Plants and microorganisms increase exudation of P-hydrolysing enzymes under P deficiency. These enzymes break down organic P, thus making $\mathrm{P}$ available for uptake. Phytase specifically catalyses the break-down of phytate, the major form of organic P in soils (Rengel and Marschner 2005). Roots excrete little, if any, phytase, whereas microorganisms (eg. Aspergillus niger) exude large amounts (Richardson et al., 2001), indirectly enabling plants to utilise phytate (Osborne and Rengel, 2002). Genetically modifying plants to excrete microbial phytase (eg. George et al., 2005) may allow plants to increase P uptake, but effectiveness of phytase is limited by the low phytate availability in soil and binding of phytase to soil particles. 

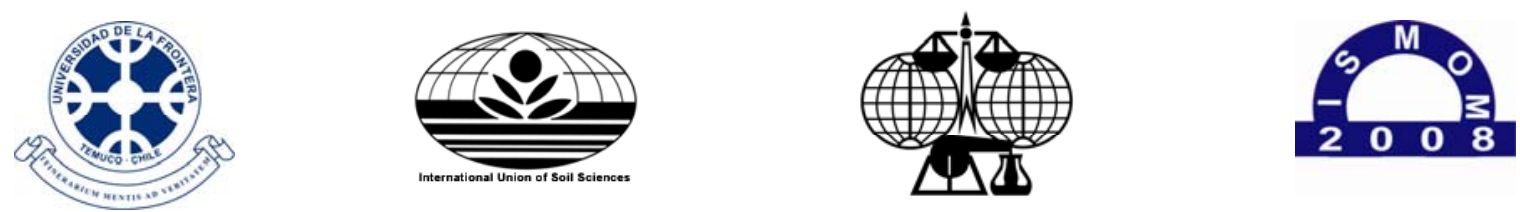

$5^{\text {th }}$ International Symposium ISMOM 2008 - November $24^{\text {th }}-28^{\text {th }}, 2008$ - Pucón, Chile

Keynote papers

Exudation of phosphatases increases when plants are P deficient (eg. Radersma and Grierson, 2004). When grown in an acidic P-deficient soil amended with Fe-P, the P-efficient Triticum aestivum genotype had a greater acid phosphatase activity in the rhizosphere than the inefficient genotype, with phosphatase activity correlating positively with growth and $\mathrm{P}$ uptake (Marschner et al., 2005b; 2006).

\section{Rhizosphere microorganisms and nutrient availability}

Root exudates are good nutrient source for microorganisms, allowing some microbial species, especially those with high growth rates and relatively high nutrient requirements such as pseudomonads (Marilley and Aragno, 1999), to proliferate rapidly in the rhizosphere. The amount and composition of root exudates affect microbial community composition which in turn will influence nutrient availability.

Plants grown with deficient vs. sufficient nutrient supply often have differential microbial communities in the rhizosphere (eg. Marschner et al., 2004; Marschner et al., 2005b; 2006; 2007). Nutrient deficiency can influence rhizosphere microorganisms either directly (by affecting their nutrition) or indirectly (via altering root morphology and exudation) (Rengel and Marschner, 2005). In addition, rhizosphere soil of different plant species shows differential composition and abundance of microbial populations (eg. Ponmurugan and Gopi, 2006). However, roots may maintain distinct rhizosphere microbial communities even when intermingling with roots of other species (Wang et al. 2007a).

Microbial community composition is influenced by soil properties as well as $\mathrm{P}$ addition (Marschner et al. 2006; Solaiman et al., 2007) and other management factors (Marschner et al., 2005b; Steenwerth et al., 2008; Steenwerth et al., 2003), with agricultural intensification resulting in decreased microbial diversity and lowering of ecosystem function (Steenwerth et al., 2005). Differential structure of microbial communities was also noted for different plant genotypes and different growth stages (Marschner et al., 2006; Solaiman et al., 2007). For example, the microbial community composition in the rhizosphere of the native Australian grass Austrostipa differed significantly from that of the two wheat genotypes, and was characterised by a high abundance of the fungal fatty acid 18:2 $\omega 6$ (Marschner et al., 2006).

Genotypic differences in the rhizosphere microbial community composition may possibly be due to differences in root exudation (chemical type and the amount). Indeed, it has been shown recently that organic acid anions in the Lupinus albus cluster root exudates can affect soil microbial community composition in the rhizosphere (Marschner et al., 2002), with an addition of artificial root exudates also showing an effect (Baudoin et al., 2003).

In contrast to Poaceae genotypes grown in a soil with neutral $\mathrm{pH}$ where differential microbial composition of the rhizosphere appeared important for differential capacity of genotypes to acquire $\mathrm{P}$ (explaining 54\% of the variation in plant growth and P uptake, Marschner et al., 2006), in Brassicaceae genotypes (grown in the same soil) root length and P mobilisation in the rhizosphere explained differential $\mathrm{P}$ acquisition, with microbial communities in the rhizosphere appearing to play only a minor role (Marschner et al., 2007). However, these relationships were dependent on soil properties, especially $\mathrm{pH}$ (Solaiman et al., 2007). In the acidic soil, while the microbial community composition in the rhizosphere of wheat differed from that in Brassicas (Wang et al., 

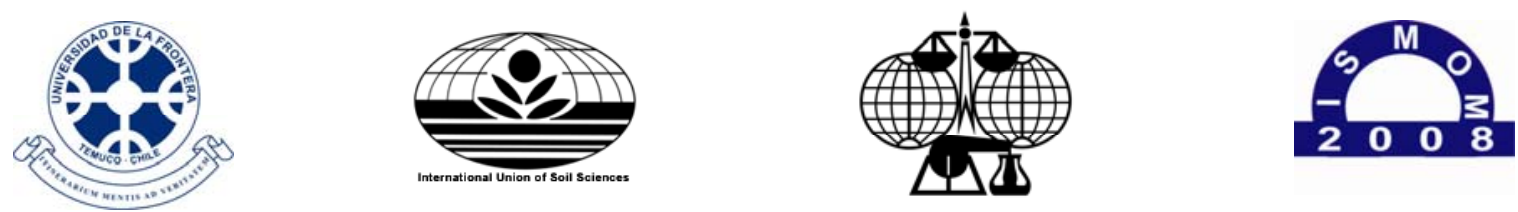

$5^{\text {th }}$ International Symposium ISMOM 2008 - November $24^{\text {th }}-28^{\text {th }}, 2008$ - Pucón, Chile

Keynote papers

2007b), the microbial P concentrations were in the same range in the rhizosphere of Brassicaceae and Poaceae, suggesting that glucosinolate release by Brassicas (followed by formation of isothiocyanates) may not necessarily have a negative effect on microbial activity in the rhizosphere (Marschner et al., 2007).

Many microbial species have the capacity to solubilise sparingly soluble $\mathrm{P}$ in vitro (Rengel and Marschner, 2005; Whitelaw, 2000). Phytate- and phosphate-solubilising bacteria have been identified, with the genus Pseudomonas being one of the most studied P-solubilising bacteria (eg. Jorquera et al., 2008; eg. Peix et al., 2003; Peix et al., 2004).

About half of culturable rhizobacteria associated with perennial ryegrass, white clover, oat and wheat were capable of solubilising P-containing compounds. The rhizosphere of pasture plants (perennial ryegrass and white clover) contained predominantly Na-phytate solubilisers, whereas in the rhizosphere of crops (oat and wheat) bacteria solubilising Ca-phosphate were more prevalent than those solubilising Na-phytate (Jorquera et al., 2008).

An effective interaction between $\mathrm{P}$ solubilisers and plants depends on (i) high population of $\mathrm{P}$ solubilisers maintained in the rhizosphere over long periods, (ii) exudation of carboxylates and protons into the rhizosphere by roots and microorganisms, (iii) low $\mathrm{P}$ uptake by microorganisms, and (iv) positive interaction with mycorrhizal fungi or other beneficial microorganisms.

P-solubilising bacteria could potentially be used as biofertilizers (see the references in Deubel and Merbach, 2005; Jorquera et al., 2008; Rengel and Marschner, 2005). However, large-scale inoculation with $\mathrm{P}$ solubilisers in farming practice is hampered by several factors that could diminish effectiveness of the introduced microorganisms: (i) most soils already contain $\mathrm{P}$ solubilisers, so the effect of inoculation may be small, (ii) introduced strains may have poor survival in the rhizosphere due to low competitiveness against indigenous, well-adapted strains, (iii) microorganisms are selected based on their $\mathrm{P}$ solubilisation in vitro in conditions ideal for growth and $\mathrm{P}$ solubilisation, whereas conditions in the rhizosphere may be far from optimal, and (iv) $\mathrm{P}$ solubilised by the microorganisms may be unavailable to plants because microorganisms take it up (Crowley and Rengel, 1999; Rengel and Marschner, 2005). It is of utmost importance that the possible contribution of P-solubilising microorganisms to crop P uptake be evaluated in realistic soil conditions in the field (cf. Jones et al. 2004) because literature abounds in reports on in vitro solubilisation of P that could not be repeated in field conditions (see Gyaneshwar et al., 2002).

\section{Manganese availability in the rhizosphere}

Yield of crops and pastures on calcareous soils is frequently limited by Mn deficiency caused by low Mn availability, rather than low Mn content in soil (Rengel 2000). The available Mn concentration was up to two orders of magnitude greater in the rhizosphere of three Banksia species (B. attenuata, B. ilicifolia and B. menziesii) than in bulk soil (Marschner et al., 2005a). An addition of $500 \mu \mathrm{g} \mathrm{MnO}_{2} \mathrm{~g}^{-1}$ soil before incubation doubled the available Mn concentration to $4 \mu \mathrm{g} \mathrm{Mn} \mathrm{g}$ soil. After 7 days incubation, the concentration of available Mn increased more than 10-fold, indicating active populations of Mn reducers (P. Marschner, unpublished).

Medicago sativa plants exude a variety of carboxylates under Mn deficiency. The amounts of exuded citrate and malonate (and to a lesser extent fumarate, malate, oxalate and lactate) under Mn 

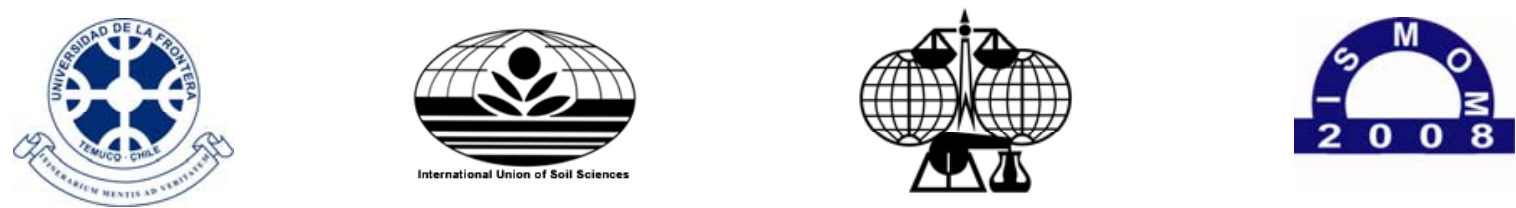

$5^{\text {th }}$ International Symposium ISMOM 2008 - November $24^{\text {th }}-28^{\text {th }}, 2008$ - Pucón, Chile

Keynote papers

deficiency were positively correlated with Mn efficiency of $M$. sativa genotypes (Gherardi and Rengel, 2003).

Manganese availability is increased in acidic rhizosphere. However, the form of $\mathrm{N}$ supplied, and therefore differences in rhizosphere acidification, had no effect on differential expression of Mn efficiency among Hordeum vulgare genotypes (see Rengel 2001) grown in calcareous soils. Strong $\mathrm{pH}$ buffering capacity of calcareous soils may contribute to preventing differential expression of Mn efficiency (eg. Tong et al., 1997).

Reduction and oxidation of Mn by microorganisms are important components of Mn cycling in soil. Fluorescent pseudomonads are effective Mn reducers, which appear to be more abundant in the rhizosphere of some Mn-efficient compared with Mn-inefficient Triticum aestivum genotypes (Rengel et al., 1998).

The bacterial communities in the Triticum aestivum rhizosphere were correlated with the concentration of DTPA-extractable $\mathrm{Mn}$ in the rhizosphere, shoot dry matter and Mn content (Marschner et al., 2003), suggesting the importance of microorganisms in plant Mn uptake.

\section{Future work}

More research into understanding the basis of qualitative and quantitative differences in root exudation is required. Given that exudation of organic compounds represents a big drain of energy and resources, thorough understanding of the regulation of the whole sequence of processes culminating in exudation of organic compounds into the rhizosphere is required before practical applications become feasible. Bioengineering the rhizosphere by adding beneficial microorganisms will require understanding of microbe-microbe and microbe-plant interactions enabling introduced microorganisms to show full activity in the targeted rhizosphere.

Keywords: Phosphorus; micronutrients; rhizosphere.

\section{References}

Adams M.A. and Pate J.S. (1992). Availability of organic and inorganic forms of phosphorus to lupins (Lupinus spp.). Plant Soil 145: 107-113.

Baudoin E., Benizri E. and Guckert A. (2003) Impact of artificial root exudates on the bacterial community structure in bulk soil and maize rhizosphere. Soil Biology \& Biochemistry 35: 1183-1192.

Cordell D. (2008). 8 reasons why we need to rethink the management of phosphorus resources in the global food system. In The Story of P Information Sheet 1. Linköping University, Sweden.

Crowley D.E and Rengel Z. (1999). Biology and chemistry of nutrient availability in the rhizosphere. In Mineral Nutrition of Crops: Fundamental Mechanisms and Implications, Ed Z Rengel. pp. 1-40. Food Products Press, New York.

Deubel A. and Merbach W. (2005). Influence of microorganisms on phosphorus bioavailability in soils. In Microorganisms in Soils: Roles in Genesis and Functions, Eds F Buscot and A Varma. pp. 177-191. Springer, Berlin Heidelberg, N.Y.

Gahoonia T.S., Asmar F., Giese H., Gissel-Nielsen G. and Nielsen N.E. (2000). Root-released organic acids and phosphorus uptake of two barley cultivars in laboratory and field experiments. Eur. J. Agron. 12: 281-289.

Gahoonia T.S., Nielsen N.E., Joshi P.A. and Jahoor A. (2001). A root hairless barley mutant for elucidating genetic of root hairs and phosphorus uptake. Plant Soil 235: 211-219.

George T.S., Simpson R.J., Hadobas P.A. and Richardson A.E. (2005). Expression of a fungal phytase gene in Nicotiana tabacum improves phosphorus nutrition of plants grown in amended soils. Plant Biotechnology Journal 3: 129-140. 

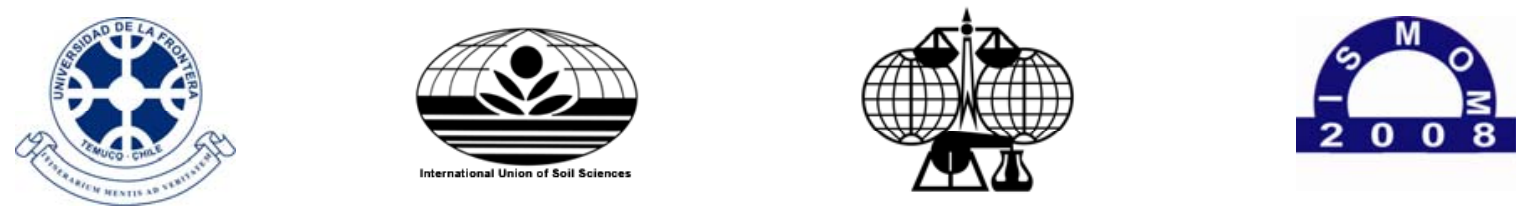

$5^{\text {th }}$ International Symposium ISMOM 2008 - November $24^{\text {th }}-28^{\text {th }}, 2008$ - Pucón, Chile

\section{Keynote papers}

Gherardi M.J. and Rengel Z. (2003). Genotypes of lucerne (Medicago sativa L.) show differential tolerance to manganese deficiency and toxicity when grown in bauxite residue sand. Plant Soil 249: 287-296.

Gyaneshwar P., Kumar G.N., Parekh L.J. and Poole P.S. (2002). Role of soil microorganisms in improving P nutrition of plants. Plant Soil 245: 83-93.

Hinsinger P. (2001) Bioavailability of soil inorganic P in the rhizosphere as affected by root-induced chemical changes: a review. Plant Soil 237: 173-195.

Hoffland E., Findenegg G.R. and Nelemans J.A. (1989). Solubilization of rock phosphate by rape. II. Local root exudation of organic acids as a response to P starvation. Plant Soil 113: 161-165.

Jasinski S.M. (2006). Phosphate Rock, Statistics and Information. US Geological Survey.

Jones D.L., Hodge A. and Kuzyakov. Y. (2004). Plant and mycorrhizal regulation of rhizodeposition. New Phytologist 163: 459-480.

Jorquera M., Hernández M., Rengel Z., Marschner P. and Mora M. (2008). Isolation of culturable phosphobacteria with both phytatemineralization and phosphate-solubilization activity from the rhizosphere of plants grown in a volcanic soil. Biol. Fertil. Soils 44: 10251034.

Krasilnikoff G., Gahoonia T. and Nielsen N.E. (2003). Variation in phosphorus uptake efficiency by genotypes of cowpea (Vigna unguiculata) due to differences in root and root hair length and induced rhizosphere processes. Plant Soil 251: 83-91.

Lambers H., Shane M.W., Cramer M.D., Pearse S.J. and Veneklaas, E.J. (2006). Root structure and functioning for efficient acquisition of phosphorus: matching morphological and physiological traits. Ann. Bot. 98: 693-713.

Liu J.Q., Samac D.A., Bucciarelli B., Allan D.L. and Vance C.P. (2005). Signaling of phosphorus deficiency-induced gene expression in white lupin requires sugar and phloem transport. Plant Journal 41: 257-268.

Marilley L. and Aragno M. (1999). Phytogenetic diversity of bacterial communities differing in degree of proximity of Lolium perenne and Trifolium repens roots. Appl. Soil Ecol. 13: 127-136.

Marschner P., Crowley D.E. and Yang C.H. (2004). Development of specific rhizosphere bacterial communities in relation to plant species, nutrition and soil type. Plant Soil 261: 199-208.

Marschner P., Fu Q.L. and Rengel Z. (2003). Manganese availability and microbial populations in the rhizosphere of wheat genotypes differing in tolerance to Mn deficiency. Journal of Plant Nutrition and Soil Science 166: 712-718.

Marschner P, Grierson P F and Rengel Z 2005a Microbial community composition and functioning in the rhizosphere of three Banksia species in native woodland in Western Australia. Appl. Soil Ecol. 28, 191-201.

Marschner P, Neumann G, Kania A, Weiskopf L and Lieberei R 2002 Spatial and temporal dynamics of the microbial community structure in the rhizosphere of cluster roots of white lupin (Lupinus albus L.). Plant Soil 246, 167-174.

Marschner P, Solaiman Z and Rengel Z 2007 Brassica genotypes differ in growth, phosphorus uptake and rhizosphere properties under Plimiting conditions. Soil Biology \& Biochemistry 39, 87-98.

Marschner P, Solaiman Z and Rengel Z 2005b Growth, phosphorus uptake, and rhizosphere microbial-community composition of a phosphorus-efficient wheat cultivar in soils differing in pH. Journal of Plant Nutrition and Soil Science 168, 343-351.

Marschner P, Solaiman Z and Rengel Z 2006 Rhizosphere properties of Poaceae genotypes under P-limiting conditions. Plant Soil 283, $11-24$.

Neumann G and Römheld V 1999 Root excretion of carboxylic acids and protons in phosphorus-deficient plants. Plant Soil 211, 121130.

Nuruzzaman M, Lambers H, Bolland M D A and Veneklaas E J 2006 Distribution of carboxylates and acid phosphatase and depletion of different phosphorus fractions in the rhizosphere of a cereal and three grain legumes. Plant Soil 281, 109-120.

Osborne L D and Rengel Z 2002 Growth and P uptake by wheat genotypes supplied with phytate as the only P source. Aust. J. Agric. Res. 53, 845-850.

Peix A, Rivas R, Mateos P F, Martinez-Molina E, Rodriguez-Barrueco C and Velazquez E 2003 Pseudomonas rhizosphaerae sp. nov., a novel species that actively solubilizes phosphate in vitro. International Journal of Systematic and Evolutionary Microbiology 53, 20672072.

Peix A, Rivas R, Santa-Regina I, Mateos P F, Martinez-Molina E, Rodriguez-Barrueco C and Velazquez E 2004 Pseudomonas lutea sp. nov., a novel phosphate-solubilizing bacterium isolated from the rhizosphere of grasses. International Journal of Systematic and Evolutionary Microbiology 54, 847-850.

Ponmurugan P and Gopi C 2006 Distribution pattern and screening of phosphate solubilizing bacteria isolated from different food and forage crops. Journal of Agronomy 5, 600-604.

Radersma S and Grierson P F 2004 Phosphorus mobilization in agroforestry: organic anions, phosphatase activity and phosphorus fractions in the rhizosphere. Plant Soil 259, 209-219.

Rengel Z 2002 Genetic control of root exudation. Plant Soil 245, 59-70.

Rengel Z 2001 Genotypic differences in micronutrient use efficiency in crops. Commun. Soil Sci. Plant Anal. 32, 1163-1186.

Rengel Z 1993 Mechanistic simulation models of nutrient uptake: A review. Plant Soil 152, 161-173. 

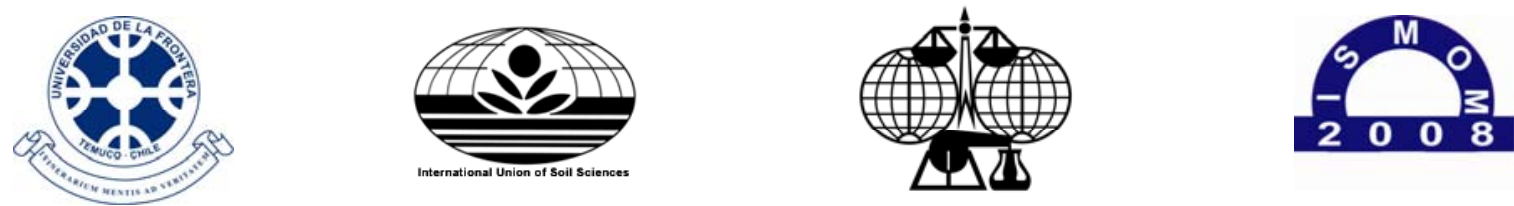

$5^{\text {th }}$ International Symposium ISMOM 2008 - November $24^{\text {th }}-28^{\text {th }}, 2008$ - Pucón, Chile

\section{Keynote papers}

Rengel Z 2000 Uptake and transport of manganese in plants. In Metal Ions in Biological Systems, Eds A Sigel and H Sigel. pp 57-87. Marcel Dekker, New York.

Rengel Z and Marschner P 2005 Nutrient availability and management in the rhizosphere: exploiting genotypic differences. New Phytologist 168, 305-312.

Rengel Z, Ross G and Hirsch P 1998 Plant genotype and micronutrient status influence colonization of wheat roots by soil bacteria. J. Plant Nutr. 21, 99-113.

Richardson A E, Hadobas P A and Hayes J E 2001 Extracellular secretion of Aspergillus phytase from Arabidopsis roots enables plants to obtain phosphorus from phytate. Plant Journal 25, 641-649.

Shen J, Rengel Z, Tang C and Zhang F 2003 Role of phosphorus nutrition in development of cluster roots and release of carboxylates in soil-grown Lupinus albus. Plant Soil 248, 199-206.

Shu L, Shen J, Rengel Z, Tang C and Zhang F 2007a Cluster root formation by Lupinus albus is modified by stratified application of phosphorus in a split-root system. J. Plant Nutr. 30, 1-3.

Shu L, Shen J, Rengel Z, Tang C, Zhang F and Cawthray G R 2007b Formation of cluster roots and citrate exudation by Lupinus albus in response to localized application of different phosphorus sources. Plant Sci. 172, 1017-1024.

Solaiman Z, Marschner P, Wang D and Rengel Z 2007 Growth, P uptake and rhizosphere properties of wheat and canola genotypes in an alkaline soil with low P availability. Biology and Fertility of Soils. Springer Verlag GmbH, Heidelberg, Germany 44, 143-153.

Steenwerth K L, Drenovsky R E, Lambert J J, Kluepfel D A, Scow K M and Smart D R 2008 Soil morphology, depth and grapevine root frequency influence microbial communities in a Pinot noir vineyard. Soil Biology \& Biochemistry 40, 1330-1340.

Steenwerth K L, Jackson L E, Calderon F J, Scow K M and Rolston D E 2005 Response of microbial community composition and activity in agricultural and grassland soils after a simulated rainfall. Soil Biology \& Biochemistry 37, 2249-2262.

Steenwerth K L, Jackson L E, Calderon F J, Stromberg M R and Scow K M 2003 Soil microbial community composition and land use history in cultivated and grassland ecosystems of coastal California. Soil Biology \& Biochemistry 35, 489-500.

Tang C and Rengel Z 2003 Role of plant cation/anion uptake ratio in soil acidification. In Handbook of Soil Acidity, Ed Z Rengel. pp 5781. Marcel Dekker, New York.

Tong Y, Rengel Z and Graham R D 1997 Interactions between nitrogen and manganese nutrition of barley genotypes differing in manganese efficiency. Ann. Bot. 79, 53-58.

Wang B, Shen J, Tang C and Rengel Z 2008 Root morphology, proton release, and carboxylate exudation in lupin in response to phosphorus deficiency. Journal of Plant Nutrition. Taylor \& Francis, Philadelphia, USA 31, 557-570.

Wang D, Marschner P, Solaiman Z and Rengel Z 2007a Belowground interactions between intercropped wheat and Brassicas in acidic and alkaline soils. Soil Biology \& Biochemistry 39, 961-971.

Wang D, Marschner P, Solaiman Z and Rengel Z 2007b Growth, P uptake and rhizosphere properties of intercropped wheat and chickpea in soil amended with iron phosphate or phytate. Soil Biology \& Biochemistry 39, 249-256.

Whitelaw M A 2000 Growth promotion of plants inoculated with phosphate-solubilizing fungi. Adv. Agron. 69, 99-151. 